\title{
HUMAN RESOURCE STRATEGY: INTRODUCING A NEW MANAGEMENT TYPOLOGY TO MAKE CHANGE STICK
}

By

\author{
Dr. MICHAEL J.R. BUTLER
}

Lecturer in Management, Aston Business School

Aston University , BIRMINGHAM, UK ABSTRACT

I maintain that ideas are events. It is more difficultto make them interesting I know, but if you fail the style is at fault. (Gustave Flaubert: Letter to Louise Colet) (15 January 1853)

Human resource management (HRM) is now being seen as a strategic activity. This recognises that change processes must include the management of human resources as part of an integrated approach to strategy. Without linking management development and business strategy, change will not stick and organisations will not develop. Contributing to the debate about integrating HR and other strategies, including linking management development and business strategy, this paper develops a new Generic Management Typology of co-existing management philosophies in order to help change agents diagnose the culture of an organisation and to modify that culture. The typology is derived from reflecting on research about the global transformation of public service organisations over the last twenty-five years.

\section{INTRODUCTION}

Human resource management (HRM) is now being seen as a strategic activity (Purcell, 1995; Storey, 1992; Tyson, 1987). Tyson (1997: 1) argues that,

'HRM is a more strategically oriented version of personnel management, with a strong emphasis on change management ... its appropriateness being entirely dependent on organisational contingencies.'

Underlying this argument are three key ideas. First, HR strategy emphasises change management because such strategy,

'is a practical managerial activity, which takes place as a consequence of an analysis of what is happening in the organisation currently, and of senior management's strategic intentions.' (Tyson, 1997: 2.)

Second, having strategic intentions is grounded in a set of ideas or management philosophies shaping the intentions. These ideas,

'may be defined as the philosophies, policies and practices which management adopt in order to achieve business-related people management activities.' (Tyson, 1998: 2.)
Third and last, HR strategy is contingent because it is influenced by a range of factors. These include:

'the history and culture of the firm, the national culture and institutional framework in which HRM exists, as well as the decision-making habits and the trade union relationships in the organisation, the labour markets in which the firm operates, and the perceptions of these variables and of HRM by people who work in the organisation.' (Tyson, 1997: 2.)

Tyson's (1997) argument recognises that change processes must include the management of human resources as part of an integrated approach to strategy. Huselid (1995) has empirical evidence to support this view. Research into over one thousand United States (US) companies shows how HRM can accelerate performance improvement but, only if it is bundled with other strategies. HRM practices were able to take performance into a higher level but, only if the productivity improvements and technically advanced systems had pushed organisational performance up to the threshold of competitiveness.

There are other studies which focus on linking management development and business strategy, so 
that change will stick and organisations will develop. Fombrun, Tichy and Devanna (1984) identified that if management development is to be a strategic HRM activity and make a significant contribution to organisational performance, there requires to be tight integration at the strategic level, high commitment at the person level and flexibility and cultural reinforcement at the organisational level. Fell and Davies (1997), however, identified that in the United Kingdom there are differences between the public and private sectors. More public sector managers than private sector managers view management development policies as a strategic tool. $46.8 \%$ of hospital managers thought that management development is very important to strategic concerns, whilst $41.7 \%$ of company managers thought the same.

As a contribution to the debate about integrating $H R$ and other strategies, including linking management development and business strategy, this paper addresses Tyson's (1997) three key ideas of change management, management philosophies and contingent factors. The paper develops a new Generic Management Typology of co-existing management philosophies in order to help change agents diagnose the culture of an organisation and to modify that culture. This approach is adopted because much of the change management literature still adopts a traditional perspective that one philosophy is replaced by another. A classic representation of this is the rational view, clearly expressed by Lewin (1951), that organisational culture can be diagnosed, unfrozen and then a desired new culture re-frozen can be set back into the host organisation. Even newer and more emergent views, for example, Balogun and Hope Hailey (1999), whilst acknowledging the complexity posed by contingent factors, still see one philosophy being replaced by another.

The typology is derived from reflecting on research about the global transformation of public service organisations over the last twenty-five years. Since about 1980, public services across the world have been increasingly subjected to market pressures and this transformation has been labelled the "New Public Management" (NPM) (Hood, 1991). Because of this phenomenon, scholars have attempted to systematise understanding about the organisational theory underpinning the emergence of new organisational strategies, structures and processes (Miles and Snow, 1994). As a consequence, previous work has been done on developing a typology of coexisting management philosophies. These philosophies co-exist because some services in some parts of the world have developed quicker than others, which means that different ways of organising are used simultaneously. The typology has been empirically tested in three studies by the author, one of which is reported in Butler (2003). There is not enough space to report the research findings here. The focus of this paper is to present and justify the typology and extend its relevance to broader organisational processes relevant to the public and private sectors, namely HR strategy and change management.

The paper outlines, briefly, the history of the rise of the NPM, discusses how other scholars have characterised NPM and argues for a new Management Typology. The argument identifies how the typology was constructed, presents the typology, locating it in broader organisational processes, and explores how the typology can be used to manage change and integrate HR strategy. Following Flaubert, the paper maintains that ideas, in this case the typology, can become an event, when they are used as a strategic tool to integrate change and $\mathrm{HR}$.

\section{The Rise of NPM}

The emergence of NPM is synonymous with the emergence of a new economy in which the old distinctions between the public and private sectors seem to be disappearing. The old economy may be characterised as public administration and the new economy as the NPM. Ferlie (1999: 2) establishes a chronology:

'From the 1940s to the late 1970s, we used to think that markets would give way to the state [public administration]; in the 1980s and early 1990s, we thought that the State would give way to the markets [NPM].'

Reflecting on the UK case, Ferlie (1999: 2) anticipates 
that a third phase may be being reached and observes that

'Now the current talk is of the "Third Way", "modernisation", and of public/private partnerships in a way which humanises but does not in my view fundamentally challenge the radical shifts of the 1980s.'

The rise is explained by a number of reasons. Economically, big government is linked to fiscal stress (Barberis, 1998), a condition exacerbated by several factors, including poor macroeconomic performances (Hood, 1995). Politically, there was the motive and opportunity to replace public administration with the NPM the New Right philosophy. The New Right draws on a range of ideas, including Public Choice Theory, which champion the market economy (Self, 1993). Socially, various demands are made both by service users, especially by an ageing population drawing their pensions longer, and by service providers, who seek more resources (Farnham and Horton, 1993, 1996).

It should be noted that outside the UK, there is speculation that there will be the demise of NPM. Johnston and Callender (2000: 601), for example, researching in Australia, suggest that

'early this century there will almost inevitably be another dramatic paradigm shift. Perhaps, the powerful voices on this occasion will be focused more on public rather than private interest, but given the evidence of history seems to be an unrealistic hope.'

The old and new economies are associated with organisational change and certain types of management action. Pettigrew, Ferlie and McKee (1992: 13) describe these changes and actions:

'Up to the mid 1980s [the old economy], the dominant problem was that of parochialism and isolation within the public sector; since the mid 1980s [the new economy] the problem has been the over-mechanistic transfer of concepts from the private to the public sectors.'

Pettigrew et al (1992: 13) also stress that there is mutual learning between the public and private sectors:

'The public sector may also provide learning for the private sector, certainly as far as handling politicians and powerful politicians is concerned.'

As a consequence, Pettigrew et al (1992: 13) noted that any learning from the NPM should extend to broader organisational processes relevant to the public and private sectors.

'There are, however, sufficient similarities to make the application of a broader range of approaches to organizational analysis within the public sector potentially fruitful, and indeed some of them originated in public (frequently hospitals) as well as private sector settings.'

In order to facilitate this transfer of knowledge, the paper will now discuss how other scholars have characterised NPM and then developed one of those characterisations to create a new Generic Management Typology.

\section{Existing NPM Characterisations}

There are three approaches in existing NPM characterisations and all acknowledge the NPM's international trends (Hood, 1995; Balfour and Grubbs, 2000), indicating 'that something significant has been happening' (Barberis, 1998: 456). At one extreme, the approach is reductionist. In other words, some scholars have characterised the NPM as one idea system. Adams and Ingersoll (1990: 165) describe the NPM as the managerial meta-myth'. This approach associates the NPM with greater market competition in the public sector and the search for expediency, efficiency, economy and the calculation of ends (Johnston and Callender, 2000; Ventriss, 2000; Dixon, Kouzmin and Korac-Kakabadse, 1998; Kaboolian, 1998).

At the opposite extreme, a second approach is complex. In other words, other scholars have simultaneously characterised the NPM as a combination of idea systems. Independently, two European scholars have identified eight NPM models. In the UK, Salter (1998) discusses the National Health Service (NHS), whilst in Sweden, Rothstein (1998) discusses Sweden's universal welfare state. Model 1 represents a more traditional view, whilst Model 8 represents its ideological extreme. Model 1 views service users as citizens who participate in government to improve service delivery (O'Toole, 1993; Ranson and Stewart, 1994; Clapham, Dix and Griffiths, 1996). In this 
Model, the state finance, provides and regulates all public services. Model 8 views service users as customers who choose between competing service providers (Waldegrave, 1993; Hoover and Plant, 1989; Saunders, 1993). In this Model, the state has no role. All functions are delivered by the private sector.

Between the two extremes, is a third approach which simplifies and reduces the number of NPM categories. Independently, scholars in the UK and the US have identified four NPM types. In the UK, Ferlie, Ashburner, Fitzgerald and Pettigrew (1996: 10) argue that:

'At least four new public management models can be discerned and while each of them represents a move away from traditional public administration models. They also contain important differences and distinctive features. A contest for interpretation is apparent ... and the degree of influence they achieve in the field may wax and wane over time.'

The four NPM Models are: The Efficiency Drive, Downsizing and Decentralization, In Search of Excellence and Public Service Orientation.

In the US, Terry (1998: 194) also identifies four NPM types or 'approaches':

'quantitative/analytic management; political management; liberation management; and marketdriven management'.

Interestingly, his approaches overlap with Ferlie et al's (1996) models. There is a tight fit between 'In Search of Excellence' and 'liberation management' both draw on Peters and Waterman's work (1982, 1993; Peters, 1992, 1993). There is also a goof fit between 'The Efficiency Drive' and 'quantitative/analytic management' and between 'Downsizing and Decentralization' and 'marketdriven management'. There is less of a fit between 'Public Service Orientation' and 'political management'. Public Service Orientation stresses accountability:

'reliance on user voice rather than customer exit ... a desire to shift power back from appointed to elected local bodies' (Ferlie et al, 1996: 15).

Political management stresses the interlocking of policy formulation and implementation at the politician/senior manager interface:

'This approach rejects outright the political/administration dichotomy. It assumes that public managers have a legitimate right to exercise political power in the policy making process' (Terry, 1998: 195).

In recent US public service literature, public administrators become public managers, hence the use of the label political management (Behn, 1998; Cook, 1998; Kaboolian, 1998; Kelly, 1998; Khademian, 1998 and Lynn, 1998).

Ferlie et al's (1996) NPM characterisation stands out as it is comprehensive (capturing the variety of welfare ideas associated with the NPM), theoretically highly developed and empirically tested (in two UK public services the NHS and education) and comparative (using more than one case study).

This paper theoretically develops Ferlie et al's (1996) NPM characterisation by deconstructing their four NPM models into four Management Types with indicators. This development creates a new typology which applies to both the public and private sectors.

\section{Typology Construction}

The discussion about the construction of the typology has three elements: the meaning of 'typology', the assumption underlying the typology and how the typology was operationalised. A dictionary definition of typology is

'the doctrine, study, or analysis and classification of types' (Longman New Universal Dictionary, 1982).

In other words, typologies are 'a sophisticated information storage and retrieval system.' (Rich, 1992: 758), combining 'greatest information content with greatest ease of information retrieval' (Mayr, 1969: 98). In organisational analysis, typologies are 'a popular approach for thinking about organizational structures and strategies.' (Doty and Glick, 1994: 230). Typologies have been used to classify and cluster similar types of organisations (Mintzberg, 1979; 1983; Miles and Snow, 1978).

Doty and Glick (1994: 244) criticise the organisational 
analysis literature because organisations do not fall into mutually exclusive sets, instead, organisations are complex and can be influenced by multiple ideal types which "fit" in different ways. In other words, one organisation can be a combination of idea systems. This means that organisations can reach the same end by following a variety of paths (Katz and Kahn, 1966, 1978; Van de Ven and Drazin, 1985), which allows for the possibility of the evolution of new organisational types (Doty and Glick, 1994; Felts and Jos, 2000).

Doty and Glick's (1994) multiple ideal types are consistent with the better known paradigm debate which has moved from a unitary to a pluralist perspective. Kuhn (1962) represents the unitary perspective which argues that one paradigm is replaced by another and they do not co-exist. Knights (1997) represents the pluralist perspective which, alternatively, argues that multiple paradigms coexist.

Doty and Glick's (1994) multiple ideal types also capture an important theme, that the process of organisational life is a dynamic and constant struggle between agent networks representing different management philosophies (Gramsci, 1971, 1996; Foucault, 1978; Hall, 1988; Clegg, 1998 and Kemeny, 1992). More than that, Ferlie et al's (1996) four NPM models and the author's four Management Types share the assumption that the NPM and organisations can be interpreted as the fall and rise of managerial ideologies (Child, 1969; Barley and Kunda, 1992; Grint, 1997; Faulks, 1998). To be explicit, each NPM model and Organisation Type symbolises a managerial ideology and together they symbolise the fall and rise of different ideas about how an organisation should be managed at any given time, some ideas are in favour and other are not, and this changes with time.

The author's typology operationalised Ferlie et al's (1996) four NPM models by supplementing their deconstruction with a wider literature review and by evaluating a prototype of the typology with a group of UK public service managers. Each of the four Management Types contains a unique combination of multiple indicators. It is the use of the indicators which theoretically develops Ferlie et al's
(1996) NPM characterisation.

\section{A New Generic Management Typology}

The new Generic Management Typology is summarised in Figure 1.

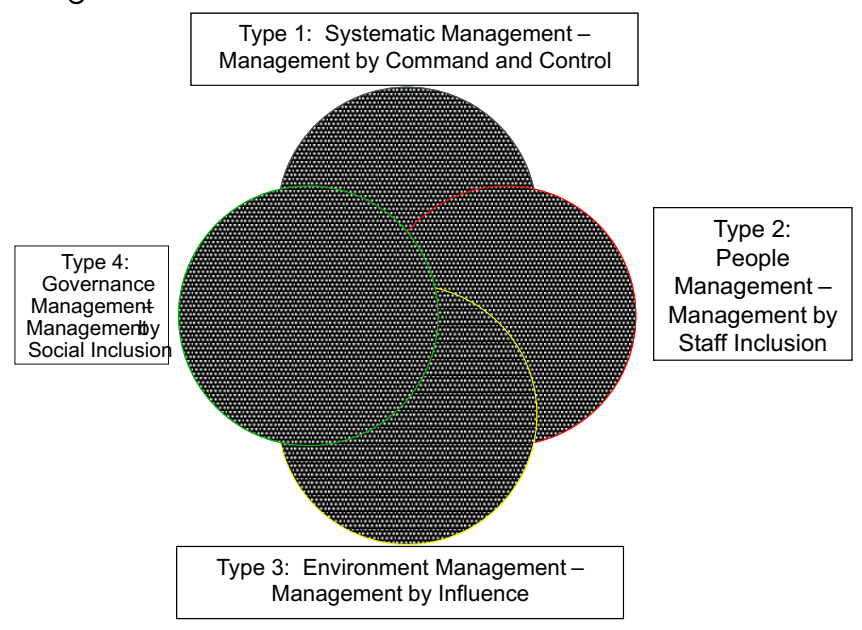

Figure 1: New Generic Management Typology

Each of the four Management Types will be discussed in turn, in the historical order from which the underpinning managerial ideology emerged. The discussion will highlight the original source of the managerial ideology, locate the ideology in the history of the NPM, give a recent policy example from both the UK and internationally and then highlight the key HR issues. All organisations will exhibit the four Types, but some will emphasise one or more Types.

Type 1: Systematic Management Managing by Command and Control

Type 1 symbolises the managerial ideology of Taylorism (Ferlie et al, 1996; Pollitt, 1990, 1993). Taylor (1911) pursued efficiency (increasing output per worker and reducing deliberate underworking), standardisation (of job performance by dividing tasks into small and specified subtasks) and discipline (establishing management by command and control). Taylorism can be more widely referred to as Systematic Management because of its focus on efficiency, standardisation and discipline. The use of Systematic Management would link it to modern management techniques like Lean Management, in which any organisational waste is managed out of any organisational process (Womack 
and Jones, 1998). Techniques associated with Systematic Management can be controlled because maximising performance is a critical issue and, as a consequence, use a particular management style management by command and control.

Type 1 'can be seen as the earliest model to emerge' (Ferlie et al, 1996: 10). It is associated with the transition from public administration. In the UK, it stretched back to least in 1951 when the Conservative government reduced income tax, introduced prescription charges, reduced NHS staffing levels and cut education spending (Glennerster, 1995).

Type 1 is currently resurgent in the UK because the auditing of public services is promoted by the Labour government (1997-ongoing) (see Power, 1996). The government, for example, is establishing clear performance frameworks for certain services, like local government (Department of the Environment, Transport and the Regions [DETR], 1999).

In the US, Balfour and Grubbs (2000: 578) draw of their consultancy experience to report that 'in an attempt to optimize the performance of a limited number of individuals', a public agency was establishing more generic or standardised working. One member of staff concluded, 'I work for everybody.' (Balfour and Grubbs, 2000: 579).

The key HR issues are the emphasis on: results-oriented governance funding outcomes, not inputs; the

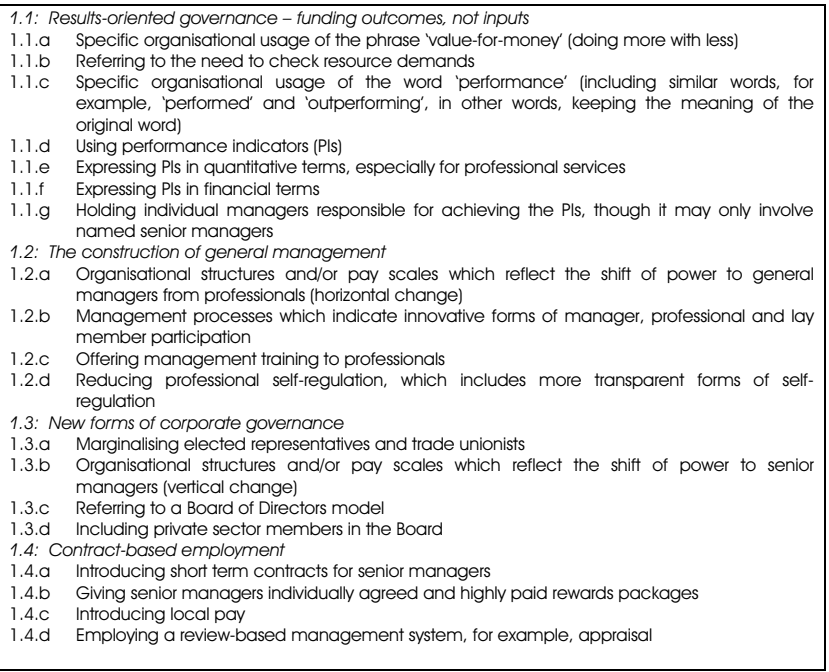

Figure 2 Type 1: Systematic Management Managing by Command and Control construction of general management; new forms of corporate governance and contract-based employment. Figure 2 relates each of these issues to a set of indicators.

Type 2: People Management Managing by Staff Inclusion

Type 2 symbolises the managerial ideology of the Human Relations school (Ferlie et al, 1996; Meek, 1988). The Human Relations school began with the Hawthorne Studies and concluded that staff are motivated by more than pay and working conditions, by their need for recognition and a sense of belonging. Motivation is shaped strongly by peer group. (Roethlisberger and Dickson, 1964.) The Human Relations school has continuously been reinvented and an enduring example is the Excellence school. During the 1980s, management consultants with best-selling texts emphasised the importance of organisational culture and the management of change (Peters and Waterman, 1982, 1993). Clearly, the common link is People Management. Techniques associated with People Management are less controlling and more empowering because maximising creativity is a critical issue and, as a consequence, use a second management style management by staff inclusion.

Type 2 emerged alongside Type 1. Whereas Type 1 is associated with the financial cost of a public service, Type 2 is associated with the quality of service being delivered.

Type 2, in UK, is not characterised by distinctive social policy activities in the sense of legislative programme. Nevertheless, policies like Best Value, at least in principle, sought a balance between the financial cost and the quality of a public service. Type 2 is interpreted broadly and it contains Ferlie et al's (1996) top-down and bottomup change and adds an external focus.

In the US, Balfour and Grubbs (2000: 580 ) report that there has been a 'recent reengineering craze within public administration'. In an attempt to 'support collaborative partnerships among ... grant recipients', a public agency, for example, collapsed 'its separate funding 
streams into a single pool of resources' (Balfour and Grubbs, 2000: 579). Balfour and Grubbs (2000: 580) conclude that there has been 'some success over time', but it 'required considerable backtracking and learning by the grant provider to sort through the difficulties of the .... Process'.

The key HR issues are the emphasis on: top-down change or mission-driven governance transforming rule-driven organisations; bottom-up change or changing the role of top management beyond systems to people; customerdriven governance meeting the needs of the service user, not the bureaucracy; enterprising governance earning rather than spending and anticipatory governance prevention rather than cure. Figure 3 relates each of these issues to a set of indicators.

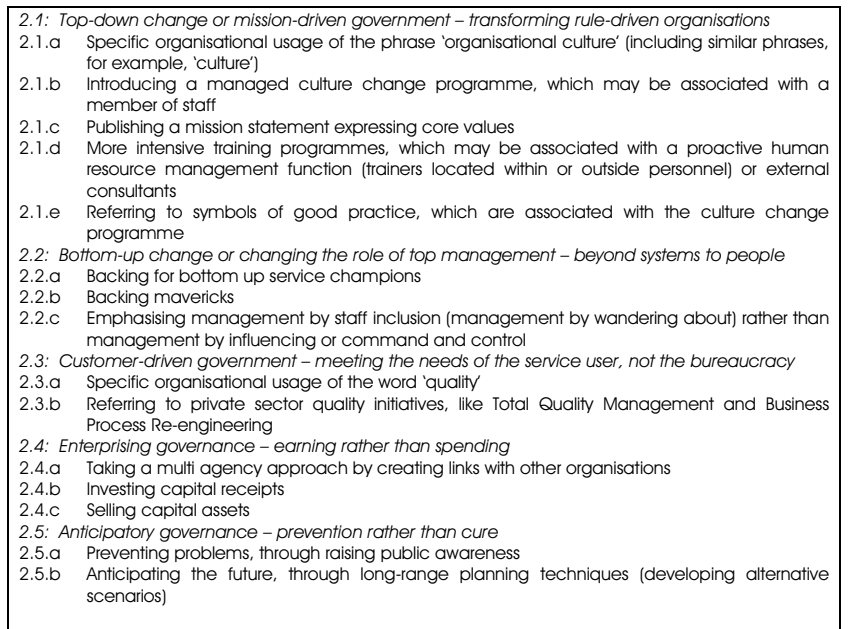

Figure 3 Type 2: People Management Managing by Staff Inclusion

Type 3: Environment Management Managing by Influence

Type 3 symbolises the managerial ideology of the market economy (Ferlie et al, 1996). It captures the current fashion within the public and private sectors to downsize and outsource (Hood, 1991; Aucoin, 1995; Boston, Martin, Pallot and Walsh, 1996). In this mode, organisations seek benefits by alliancing or contracting externally with other organisations. In a globalised economy, alliancing or contracting can take place internationally. This is Environment Management. Techniques associated with Environment Management draw on multi-media technology because maximising effective communication is a critical issue and, as a consequence, use a third management style management by influence.

Type 3 can currently be seen as increasing significance, undermining and contradicting some of the earlier changes brought about as a result of the diffusion of Type 1 ideas (Ferlie et al, 1996). It is associated with the full expression of the New Right philosophy, its ideological extreme (Hood, 1991; Aucoin, 1995; Boston et al, 1996). Type 3, internationally, characterised by a 'decisive break with previous policy' (Wilson, 1993: 29) which in retrospect will be seen as critical in the history of a specific country's social policy. In UK, the decisive break came in 19881989, the Conservative government began to apply a programme of market-oriented change to the welfare of state (Le Grand, 1991).

Type 3 has continued in the UK despite the election of the Labour government. Although Best Value is couched in the discourse of a transition from compulsory to voluntary competition, it does, however, accept the principle of competition and by implication privatisation:

'fair and open competition will, in the Government's view, most often be the best way of demonstrating that a function is being carried out competitively. Such competition is expected to play an essential and enduring role in ensuring best value' (Local Government Act, 1999: 12).

Type 3 has been taken to greater lengths in the US. Timney and Kelly (2000: 555) report that, in 1999,

'the State of New York gave welfare recipients an electronic banking card in lieu of a check. Under a contract with Citigroup, the parent of Citibank and the nation's largest financial services company declared that the state would no longer issue individual checks'.

Unfortunately, 'Perhaps the greatest impact on the poor, however, is the charges that are taken for each transaction, effectively reducing the welfare benefit'.

The key HR issues are the emphasis on: catalytic governance steering rather then rowing; market regulation; downsizing and managing by influence. 
Figure 4 relates each of these issues to a set of indicators.

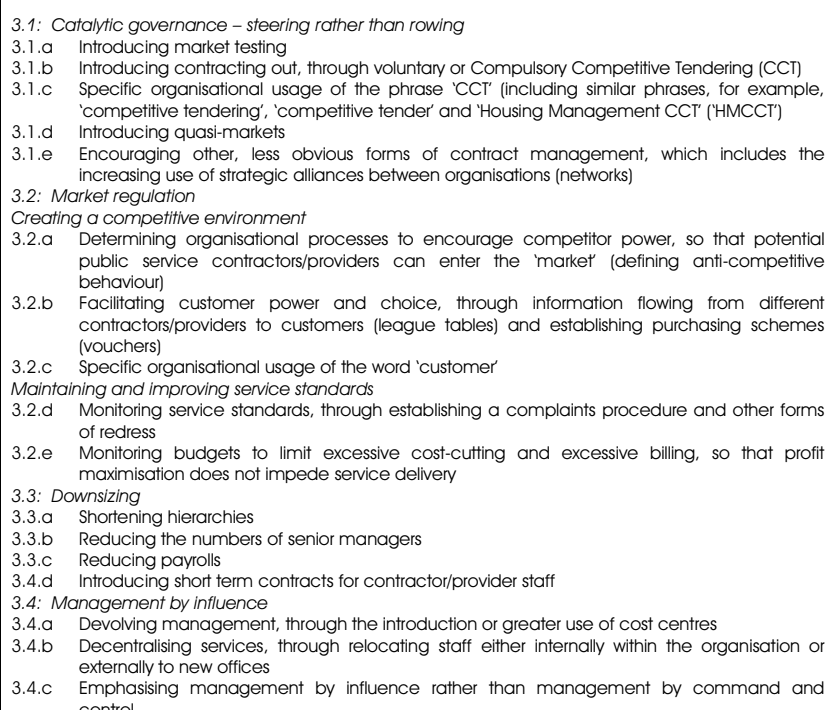

Figure 4 Type 3: Environment Management Managing by Influence

Type 4: Governance Management Managing by Social Inclusion

Type 4 symbolises the attempt to combine public and private sector activities in a Third Way. There is a fusion of left and right political values. The traditional left political value of social justice is fused with the traditional right political value of the individual rights and are conditional on responsibilities. (Giddens, 1998.) Social theory translates into organisational theory through a 'fusion of private and public sector management ideas' (Ferlie et al, 1996: 14). Systematic, People and Environment Management are fused with the renewal of democracy Governance Management. This is an emergent managerial ideology. In the wake of various private sector scandals, like Enron, corporate governance techniques are being devised, implemented and regulated. Techniques associated with Governance Management are ethics driven because maximising trust is a critical issue and, as a consequence, use a fourth management style management by social inclusion.

Type 4 'is presently the least well developed and is still to reveal its full potential.' (Ferlie et al, 1996: 14). If Johnston and Callender (2000) are right about the demise of the NPM, then it is likely that its replacement will emerge from
Type 4. This is because Type 4 is a contested area, debating the future of work.

Type 4 is characterised by a critique of Type 3. In the UK, in central government, for example, quangos (quasi nongovernmental organisations, that-is-to-say, organisations linked to, but not managed by, the government) still exist but there is 'a progressive shift in appointments from business representatives to local councillors (usually Labour Party councillors)' (Ferlie et al, 1996: 17).

As with Type 3, Type 4 has been taken to greater lengths in the US. Timney and Kelly (2000: 565-6) report that

'the Missouri state energy office ... contracted with a nongovernmental organization (NGO), the Kansas City Metropolitan Energy Center, to develop the citizen participation process ... [which] involved hundreds of citizens ... The result was that proposals had significant political support and sailed through the legislature.'

The key HR issues are the emphasis on: transformations and predicaments about choices available; accountability through community governance empowering rather than serving; accountability through elected representatives and designing public service governance. Figure 5 relates each of these issues to a set of indicators.

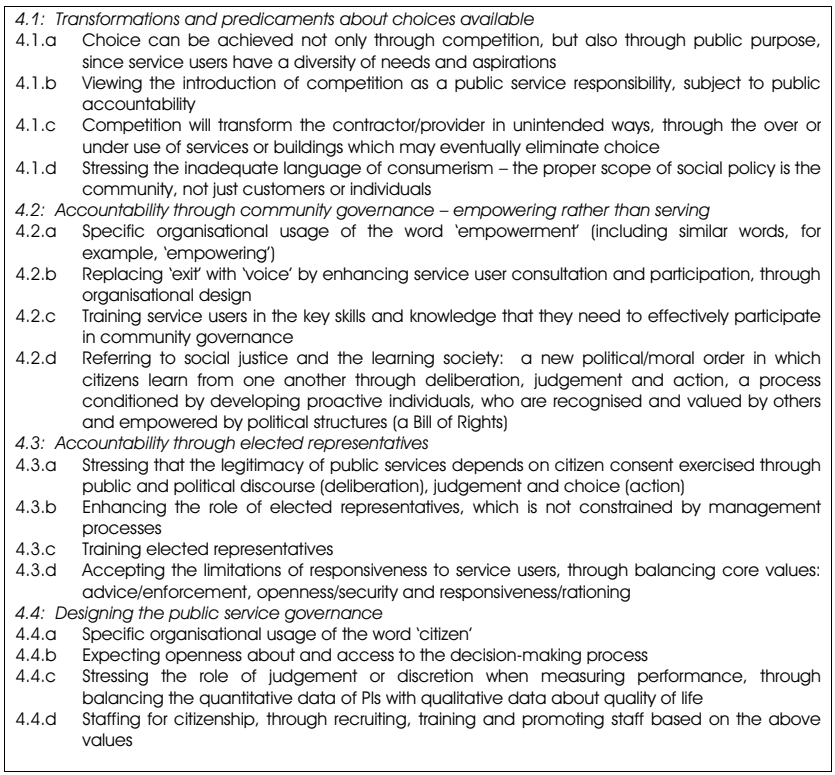

Figure 5 Type 4: Governance Management Managing by Social Inclusion 
The Typology as a Strategic Tool to Integrate Change and $H R$

Having presented the typology and located it in broader organisational processes, namely managerial ideologies, policy change and key HR issues, the paper explores how the typology can be used to manage change and integrate HR strategy.

The typology can be used to manage change by returning to Tyson's (1997) three key ideas of change management, management philosophies and contingent factors. Two other ideas are added in order to make Tyson's (1997) ideas operational. A strategic tool with five activities is itemised below to integrate the new Generic Management Typology, change and HR. This is the only approach and it should not be seen as prescriptive or sequential, other approaches should be devised, used and assessed. The author has empirically used the approach up to the end of the diagnosis activity (Butler, 2003). His undergraduate students have used all the five activities with case study organisations of their choice to learn about organisational analysis and the practice of change management.

\section{Activity 1 Organisational Diagnosis}

The paper develops a new Generic Management Typology of co-existing managerial ideologies in order to help change agents, diagnose the culture of an organisation and to modify that culture. Diagnosis is achieved by giving change agents four distinct Types of organisational behaviour, each with a set of indicators of that behaviour. The change agents can find evidence for each indicator within their host organisation. Evidence can be found by using different methods: documentary, ethnographic and interview. A judgement can be reached about, which Type is emphasised. The identification of this Type, founded on evidence, will diagnose the dominant organisational culture. Type 1, for example, may be the dominant Type: Systematic Management, Managing by Command and Control.

Activity 2 PerformanceAssessment

Associated with Activity 1 , is an assessment of organisational performance. If performance is satisfactory, then no modification needs to be made to the organisational culture. However, if performance needs to be improved, then the change agents have two choices. First, the organisational processes that already exist can be improved, for instance, if Type 1 is dominant, then processes linked to this Type can be improved. Second, the change agents may decide to modify the culture. This can be achieved by finding a change strategy to emphasise an alternative Type, for example, moving the dominant culture from Type 1 to one of the other Types. Processes linked to the new Type can be improved.

\section{Activity 3 Operational Context}

The decision about which Type to choose is linked to the operational context of the organisation. It may be felt that in a fast-moving context, staff creativity is more valued in order to promote innovation as a competitive advantage. This means that Type 2 will be selected and the processes linked to this Type will be improved. Type 2 focuses on People Management Managing by Staff Inclusion. Other contexts will require alternative strategies and the selection of a different Type.

\section{Activity 4 Integrating HR}

Having made this decision, the change agents will integrate HR into the change strategy. Having selected Type 2, managers will be trained in People Management skills and knowledge. This may take the form of a Management Development Programme for all staff, or coaching individual staff through specific training events. The managers will adopt a style of staff inclusion and, more specifically, would adapt organisational processes to mirror the new style. Some of these processes are specified in Figure 3.

\section{Activity 5 Continuous Evaluation}

As with any organisational intervention, continuous evaluation of the process is needed. Evaluation should take place at all stages of all stages. Change is an iterative process, in which the emergence of new organisational strategies, structures and processes needs constant monitoring (Miles and Snow, 1994).

By taking this approach, it is envisaged that change 
management should stick. Change should stick because the new Generic Management Typology has been constructed to reflect the complexity of organisational life, that organisations simultaneously operate within different modes the four Types. Future research should test the typology and its application in different organisational contexts to build up case studies for scholars, students and mangers to use in business education and practical management.

\section{Concluding Remarks}

The paper contributes to the perennial debate about how to manage staff by focusing on integrating HR and other strategies, including linking management development and business strategy. In particular, it addresses Tyson's (1997) three key ideas of change management, management philosophies and contingent factors. The three ideas are then linked to two other ideas in order to make Tyson's (1997) ideas operational. A strategic tool with five activities is suggested to integrate the new Generic Management Typology, change and HR.

A novel contribution is the development of new Generic Management Typology. Its newness lies in its acknowledgement that there are co-existing managerial ideologies. In order to manage change, the process of organisational life has been interpreted as a dynamic and constant struggle between agent networks representing different management philosophies, the fall and rise of the four Management Types.

A further novel contribution is the transfer of knowledge from the public sector to a wider audience. In particular, the paper theoretically develops Ferlie et al's (1996) NPM characterisation by deconstructing their four NPM models into four Management Types with indicators. This development creates a new, more generic, Management Typology which applies to both the public and private sectors.

\section{References}

[1]. Adams, G.B. and Ingersoll, V.H. (1990) 'Culture, Technical Rationality and Organizational Culture', American Review of Public Administration, 20:4, December, pp 285-302.
[2]. Aucoin, P. (1995) The New Public Management: Canada in Comparative Perspective, Ashgate Publishing Company: Montreal, Canada.

[3]. Balfour, D.L. and Grubbs, J.W. (2000) 'Character, Corrosion and the Civil Servant: The Human Consequences of Gobalization and the New Public Management', Administrative Theory \& Praxis, 22:3, September, pp 570-584.

[4]. Balogun, J. and Hope Hailey, V. (1999) Exp/oring Strategic Change, Pearson Education Limited: Harlow.

Barberis, P. (1998) 'The New Public Management and a New Accountability', Public Administration, 76, Autumn, pp 451-470.

[5]. Barley, S.R. and Kunda, G. (1992) 'Design and Devotion: Surges of Rational and Normative Ideologies of Control in Managerial Discourse', Administrative Science Quarterly, 37:3, September, pp 363-399.

[6]. Behn, R.D. (1998) 'What Right Do Public Managers Have To Lead?', Public Administration Review, 58:3, May/June, pp 209-224.

[7]. Boston, J.; Martin, J.; Pallot, J. and Walsh, P. (1996) Public Management: The New Zealand Model, Oxford University Press: Auckland, New Zealand.

[8]. Butler, M.J.R. (2003) 'Managing from the Inside Out: Drawing on 'Receptivity' to Explain Variation in Strategy Implementation', British Journal of Management, 14, Special Issue, December, pp S47-S60.

[9]. Child, J. (1969) British Management Thought, Allen and Unwin Limited: London.

[10]. Clapham, D.; Dix, J. and Griffiths, M. (1996) Citizenship and Housing Shaping the Debate, Institute of Housing: Coventry.

[11]. Clegg, S. (1998) 'Foucault, Power and Organizations' in A. McKinlay and K. Starkey (eds) Foucault, Management and Organization Theory, Sage: London, pp 29-48.

[12]. Cook, B.J. (1998) 'Politics, Political Leadership, and Public Management', Public Administration Review, 58:3 May/June, pp 225-230.

[13]. DETR (1999) Best Value and Audit Commission 
Performance Indicators for 2000/2001, December, DETR: London.

[14]. Dixon, J.; Kouzmin, A. and Korac-Kakabadse, N. (1998) 'Managerialism Something Old, Something Borrowed, Little New: Economic Prescription Versus Effective Organizational Change in Public Agencies', International Journal Of Public Sector Management, 11:2/3 pp 164-187.

[15]. Doty, D.H. and Glick, W.H. (1994) 'Typologies as a Unique Form of Theory Building: Toward Improved Understanding and Modelling', Academy of ManagementReview, 19:2, April, pp 230-251.

[16]. Farnham, D. and Horton, S. (1993, 1996 edition) Managing the New Public Services, MacMillan Press Limited: Basingstoke and London, Second Edition.

[17]. Faulks, K. (1998) Citizenship in Modern Britain, Edinburgh University Press: Edinburgh.

[18]. Fell, A. and Davies, T. (1997) 'Business Strategy and Management Development A Symbiotic Relationship?' in S. Tyson (ed) The Practice of Human Resource Strategy, Pitman Publishing: London, pp 102-135.

[19]. Felts, A.A. and Jos, P.H. (2000) 'Time and Space: The Origins and Implications of the New Public Management', Administrative Theory \& Praxis, 22:3, September, pp 519-533.

[20]. Ferlie, E. (1999) 'The Rise of the New Public Management', unpublished Inaugural Lecture, Imperial College, UK, 9 March.

[21]. Ferlie, E.; Ashburner, L.; Fitzgerald, L. and Pettigrew, A. (1996) The New Public Management in Action, Oxford University Press: Oxford.

[22]. Fombrun, C.J., Tichy, N.M. and Devanna, M.A. (1984) Strategic Human Resource Management, Wiley: New York.

[23]. Foucault, M. (1978) 'The History of Sexuality' in A. Easthope and K. McGowan (eds) A Critical and Cultural Theory Reader, Open University Press: Buckingham, 1997, pp 90-95.

[24]. Giddens, A. (1998) The Third Way The Renewal of SocialDemocracy, Polity Press: Cambridge.
[25]. Glennerster, H. (1995) British Social Policy Since 1945, Blackwell: Oxford.

[26]. Gramsci, A. (1971, 1996 edition) Selection from the Prison Notebooks, Lawrence and Wishart: London, Translated and Edited by Q. Hoare and G. Smith.

[27]. Grint, K. (1997) Fuzzy Management Contemporary Ideas and Practices at Work, Oxford University Press: Oxford.

[28]. Hall, S. (1988) 'The Toad in the Garden: Thatcherism Among the Theorists' in C. Nelson and L. Grossberg (eds) Marxism and the Interpretation of Culture, MacMillan Education Limited: Basingstoke and London, pp 35-57.

[29]. Hood, C. (1991) 'A New Management for All Seasons?', Public Administration, 69, Spring, pp 3-19.

[30]. Hood, C. (1995) 'The New Public Management in the 1980s: Variations on a Theme', Accounting Organizations And Society, 20:2/3 pp 93-109.

[31]. Hoover, K. and Plant, R. (1989) Conservative Capitalism, Routledge: London.

[32].Huselid, M. (1995) 'The Impact of Human Resource Management Practices on Turnover, Productivity and Corporate Financial Performance', Academy of ManagementJournal, 39:3, pp 635-673.

[33].Johnston, J. and Callender, G. (2000) 'Multiple Perspectives on Economic Rationalism and the New Managerialism: Power and Public Interest?', Administrative Theory \& Praxis, 22:3, September, pp 585604.

[34]. Kaboolian, L. (1998) 'The New Public Management: Challenging the Boundaries of the Management Vs. Administration Debate', Public Administration Review, 58:3, May/June, pp 189-193.

[35]. Katz, D. and Kahn, R.L. (1966, 1978 edition) The Social Psychology of Organizations, Wiley: New York, US, Second Edition.

[36]. Kelly, R.M. (1998) 'An Inclusive Democratic Polity, Representative Bureaucracies, and the New Public Management', Public Administration Review, 58:3, May/June, pp 201-208.

[37]. Kemeny, J. (1992) Housing and Social Theory, 
Routledge: London.

[38]. Khademian, A.M. (1998) 'What Do We Want Public Managers To Be? Comparing Reforms', Public Administration Review, 58:3, May/June, pp 269-273.

[39]. Knights, D. (1997) 'Organization Theory in the Age of Deconstruction: Dualism, Gender and Post-Modernism Revisited', Organization Studies, 18:1 pp 1-19.

[40]. Kuhn, T.S. (1962) The Structure of Scientific Revolutions, The University of Chicago Press: Chicago, US.

[41]. Le Grand, J. (1991) 'Quasi-Markets and Social Policy', The Economic Journal, 101, September, pp 1256 1267.

[42]. Lewin, K. (1951) Field Theory in Social Science: Selected Papers, Tavistock: London.

[43]. Local Government Act (1999) Part 1 Best Value, DETR Circular 10/99, 14 December, DETR: London.

[44]. Longman New Universal Dictionary (1982) Longman Group Limited: Harlow.

[45]. Lynn, L.E. (1998) 'The New Public Management: How to Transform a Theme into a Legacy', Public Administration Review, 58:3, May/June, pp 231-237.

[46]. Mayr, E. (1969) Principles of Systematic Zoology, McGraw-Hill Book Company: New York, US.

[47]. Meek, V.L. (1988) 'Organisation Culture: Origins and Weaknesses', Organization Studies, 9:4 pp 453-473.

[48]. Miles, R.E. and Snow, C.C. (1978) Organisation Strategy, Structure, and Process, McGraw-Hill Book Company: New York, US.

[49]. Miles, R.E. and Snow, C.C. (1994) Fit, Failure and the Hall of Fame, The Free Press: New York.

[50].Mintzberg, H.T. (1979) The Structuring of Organisations, Prentice Hall: Englewood Cliffs, US.

[51]. Mintzberg, H.T. (1983) Structure In Fives: Designing Effective Organizations, Prentice Hall: Englewood Cliffs, US.

[52]. O'Toole, B.J. (1993) 'Editorial Permanent Secretaries, Open Competition and the Future of the Civil Service', Public Policy And Administration, 8:3, Winter, pp 1-3.
[53]. Peters, T. (1992, 1993 edition) Liberation Management, Pan Books Limited: London.

[54]. Peters, T. and Waterman, R. (1982, 1993 edition) In Search of Excellence, Harper Collins: New York, US.

[55]. Pettigrew, A.M.; Ferlie, E. and McKee, L. (1992) Shaping Strategic Change Making Change in Large Organisations: The Case of the National Health Service, Sage: London.

[56]. Pollitt, C. (1990, 1993 edition) Managerialism and the Public Services, Blackwell: Oxford, Second Edition.

[57]. Power, M. (1996) 'Making Things Auditable', Accounting, Organizations And Society, 21:2/3 pp 289315.

[58]. Purcell, J. (1995) 'Corporate Strategy and Human Resource Management' in J. Storey (ed) Human Resource Management: A Critical Text, Routledge: London, pp 63-86.

[59]. Ranson, S. and Stewart, J. (1994) Management for the Public Domain Enabling the Learning Society, The MacMillan Press Limited: Basingstoke and London.

[60].Rich, P. (1992) 'The Organizational Taxonomy: Definition and Design', Academy Of Management Review, 17:4, October, pp 758-781.

[61]. Roethlisberger, F.J. and Dickson, W.J. (1964) Management and the Worker, John Wiley: New York, US.

[62]. Rothstein, B. (1998) Just Institutions Matter The Moral and Political Logic of the Universal Welfare State, Cambridge University Press: Cambridge.

[63]. Salter, B. (1998) 'Citizenship and the Politics of Welfare The Case of the NHS', Public Policy And Administration, 13:3, Autumn, pp 38-55.

[64]. Saunders, P. (1993) 'Citizenship in a Liberal Society' in B. Turner (ed) Citizenship and Social Theory, Sage: London, pp 57-90.

[65]. Self, P. (1993) Government by the Market? The Politics of Public Choice, MacMillan Press Limited: Basingstoke and London.

[66]. Storey, J. (1992) Development in the Management of Human Resources, Blackwell: Oxford. 
[67]. Taylor, F.W. (1911) The Principles of Scientific Management, Harper and Brothers: New York, US.

[68]. Terry, L.D. (1998) 'Administrative Leadership, NeoManagerialism, and the Public Management Movement', Public Administration Review, 58:3, May/June, pp 194-200.

[69]. Timney, M.M. and Kelly, T.P. (2000) 'New Public Management and the Demise of Popular Sovereignty', Administrative Theory \& Praxis, 22:3, September, pp 555569.

[70]. Tyson, S. (1987) 'The Management of the Personnel Function', Journal of Management Studies, 24:5, pp 4953.

[71]. Tyson, S. (1997) The Practice of Human Resource Strategy, Pitman Publishing: London.

[72]. Van de Ven, A.H. and Drazin, R. (1985) 'The Concept of Fit in Contingency Theory' in L.L. Cummings and B.M. Staw (eds) Research in Organizational
Behaviour, JAI Press: Greenwich, US, 7, pp 333-365.

[73]. Ventriss, C. (2000) 'New Public Management: An Examination of its Influence on Contemporary Public Affairs and its Impact on Shaping the Intellectual Agenda of the Field', Administrative Theory \& Praxis, 22:3, September, pp 500-518.

[74]. Waldegrave, W. (1993) The Reality of Reform and Accountability in Today's Public Service, Public Finance Foundation, BDO Consulting and Chartered Institute of Public Finance and Accountancy: London.

[75]. Wilson, J. (1993) 'Political Environment and Public Service Activity' in J. Wilson and P. Hinton (eds) Public Services and the 1990s Issues in Public Service Finance and Management, Tudor Business Publishing Limited: Sevenoaks, pp 22-40.

[76]. Womack, J.P. and Jones, D.T. (1998) Lean Thinking Banish Waste and Create Wealth in Your Organisation, Touchstone: London.

\section{ABOUT THE AUTHOR}

Dr. Michael J.R. Butler is presently working as a lecturer in Management in Aston Business School. He obtained his PhD in Management and Strategic Management Group in the year 2000 from the University of Warwick. He is an editor at Cranfield School of Management's Working Paper Series. His research interests are change management/strategy, decision-making (behavioral), discourse analysis, government and society and organization behavior/theory. In 2005, he received the Aston Excellence Teaching Award. From 2006, he has been listed in "Who's Who in the World".

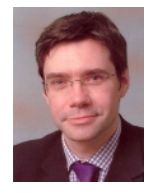

